\title{
Identifying Correlation between Reading Strategies Instruction and L2 Text Comprehension
}

\author{
Sumaira Qanwal \\ Department of English, COMSATS Institute of Information Technology, Pakistan \\ Shahzad Karim \\ Department of English, The Islamia University of Bahawalpur, Pakistan; \\ English Language Institute, King Abdulaziz University, Jeddah, Saudi Arabia
}

\begin{abstract}
The present study aims at exploring correlation between reading strategies instruction and proficiency in text comprehension. The task is carried out by investigating the current practices of teaching and learning of $\mathrm{L} 2$ reading comprehension skills of the higher level L2 learners of English in Pakistan. In this regard, initially, the extent to which teachers incorporate reading strategies instruction into their teaching of ESL reading skills is analyzed; and students' proficiency in L2 text comprehension is evaluated. Subsequently, correlation between the two variables is identified by applying Pearson Product-moment correlational test on the statistical scores attained for each variable. The research has employed both quantitative and qualitative measures for data collection and analysis. The research instruments include a questionnaire for students pertaining to the availability of reading strategy instruction, and a reading comprehension test. The results acquired through the collected data and their statistical analyses have highlighted a strong positive correlation between reading strategies instruction and learners' proficiency in text comprehension.
\end{abstract}

Index Terms—reading strategies instruction, text comprehension, ESL reading skills, reading proficiency

\section{INTRODUCTION}

English, being an international language, offers a rich source of information, knowledge and learning throughout the world. In Pakistan, it enjoys the status of a second language. A greater part of knowledge and information in Pakistan is accessible to the common public in the form of printed materials in English language i.e. books, weekly/monthly magazines, daily newspapers, journals, newsletters, fliers, brochures and advertisements etc. Hence, there is a need to develop the reading skills of the L2 learners of English so that they can easily respond to the world which brims with a good deal of knowledge in this language.

Reading is one of the most important skills for academic learning and success "Reading is essential for success in acquiring a second language. After all, reading is the basis of instruction in all aspects of language learning" (Mikulecky, 2008, p.1). Eskey (2002) considers reading as a major source of comprehensible input in language learning, and recognizes it as a skill that is most needed to be employed by the serious learners. When we talk about reading as a skill, there are two basic things involved: first, to be able to identify and recognize the written symbols on the page; and second, to understand and interpret those symbols in order to decode meanings. The former (knowing how to read) is simply named as reading or reading ability, whereas the latter is differentiated as reading comprehension or comprehension proficiency. There are many reasons which make reading comprehension an important learning skill. If a person is able to recognize the written symbols but is not able to understand the meaning, it means that he has not got much.

At higher education level i.e. university level, reading is as important a skill as any of the other skills involved. When the learners make transition from their school/college to the university, they have to face changes in the requirements of learning. Same is the case with reading. The nature of reading changes as the learners shift from college to university learning because of the sharp increase in reading load and difficulty. Now, more and more independent reading is required to learn significant modules of a course of study. Hence, students require transforming their passive style of reading into actively involved reading. However, being not familiar with or habitual of active reading, the students fail to construct accurate comprehension of the presented materials. As a natural outcome, they start disliking reading tasks which actually form the basis of their true learning. At this stage, it is very essential to eliminate students' fear of reading tasks. Here, the role of the teachers is very importance because it is the teachers who can make students overcome their ill-feelings about reading by developing active reading skills in them. This can be carried out by developing and promoting active reading skills and strategies among ESL students. Reading strategies are the strategies which help to promote the comprehension of the written texts. They help to make one's reading an active process, as by 
using these strategies, a reader can actively interact with the text and get a variety of meanings. Teaching these strategies to ESL learners in a formal language classroom is termed as reading strategies instruction.

Having realized the importance of the reading skills at university level education, the researchers were motivated to know whether these skills are being focused at higher education level in their own locality i.e. Bahawalpur, a district in the region of Southern Punjab in Pakistan. For this purpose, The Islamia University of Bahawalpur was selected as a research site because this is the only university providing graduate and postgraduate level education in the area the researchers belong to i.e. the area of Southern Punjab. The researchers planned to determine the nature and extent of reading strategies instruction practiced by the teachers of The Islamia University of Bahawalpur in their ESL classrooms and the subsequent impact of this type of instruction on students' reading comprehension ability.

\section{Research Questions}

The study investigates the following research questions:

1. To what extent is reading strategies instruction being provided to the L2 learners of English?

2. To what extent are the L2 learners of English proficient in text comprehension?

3. Is there any correlation between reading strategies instruction and learners' proficiency in text comprehension?

\section{THEORETICAL BACKGROUND}

\section{A. Reading}

The word 'reading' has been so variously defined by experts that it is hard to provide a comprehensive definition of the term. However the following three major categories can be categorized on the basis of some commonly recognized definitions:

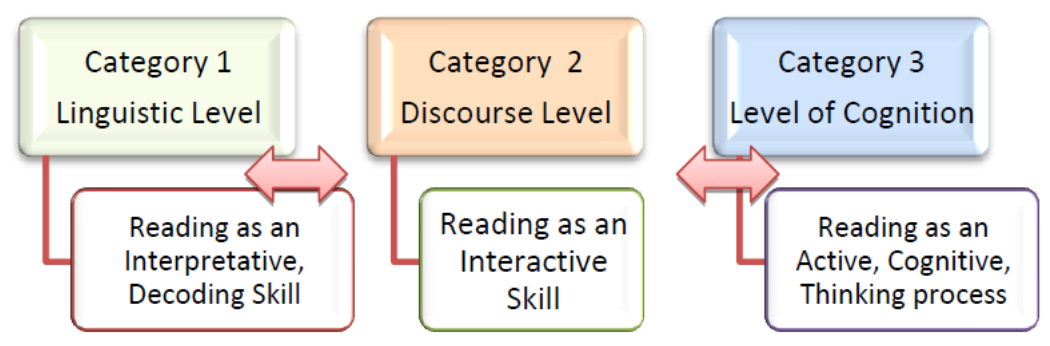

Figure 1: Commonly recognized definitions of 'Reading'

Note: The mediation arrows represent the inter-connection among the three leveled-definitions of reading.

\section{Reading as an Interpretative, Decoding Skill}

Reading is regarded as an interpretative or decoding skill as it engages the reader to decode the textual message by identifying printed symbols in order to interpret their meanings. Many researchers define reading as an interpretative process. For example, Urquhart and Weir (1998, p. 22) state that reading "is the process of receiving and interpreting information encoded in language form via the medium of print." Similarly, Williams (1996) terms reading as a process of looking at and understanding a written text.

\section{Reading as an Interactive Skill}

Reading is also defined in terms of an interactive process. For example, Ransom (1978) affirms that reading is a conversation between the writer and the reader. Likewise, Shaw (1959) explains that reading is the communication of thoughts, moods, and emotions through which one receives from others their ideas and feelings (cited in Rahman, 2007). Nuttall (1996, p. 4) regards reading as the process of "getting out of the text as nearly as possible the message the writer puts into it."

\section{Reading as an Active, Cognitive, Thinking Process}

Some of the experts regard reading as an active, conceptual, thinking process. Rauch and Weinstein (1968) term reading as an active, alert thinking process where the reader matches the writer thought for thought. Shaw (1959) cited by Rahman (2007), supports the idea by stating that reading is thinking with the author and absorbing his ideas. Hence, Reading is not a passive skill. It engages the reader in a kind of mental exercise. It is not just an act of going through the text, rather it demands certain attitudes and reactions on the part of the reader towards the text.

\section{B. Reading Comprehension}

Reading is often regarded as a twofold process: the first thing involved in reading is to identify and recognize the written symbols (words); next step is to straighten the way for perception and internalization of the meaning. Such is the elaboration of the reading process presented by Dechant (1982, p. 288) who explains 'word identification' and 'comprehension' as the two stages of the process of reading. Comprehension is defined as reading text with understanding. It is the process of making sense of words, sentences and connected speech. Rice (2009, p. 2) suggests that comprehension is not an outcome in itself. It is rather a process "through which a reader interacts with a text to construct meaning". 


\section{Reading Comprehension Strategies}

The skills or strategies needed to understand a text are called reading strategies or comprehension strategies. Adler (2001) reflects that comprehension strategies are conscious plans - sets of steps that good readers use to make sense of the text. The findings of the last 25 years studies have led to the common realization that good readers use comprehension strategies to facilitate the construction of meaning.

\section{Types of Reading Comprehension Strategies}

Reading strategies have been classified differently by different experts. Some of the researchers have classified reading strategies into three parts according to their use, i.e. before-reading, while-reading and post-reading strategies. For example, Pressley \& Wharton-McDonald (1997) indicate that good readers of all ages engage in conscious, active comprehension strategies before, during and after reading. Rice (2009) supports the claim by enlisting various types of pre-reading, while-reading and post-reading strategies a reader might use. Before reading, according to him, such strategies may be used as setting goals for reading, thinking about what is already known about the topic and examining the structure of a text. While-reading strategies may include activating prior knowledge, making connections among important ideas, resolving comprehension difficulties, making notes in the margins or underlining important portions of the passage. Post-reading strategies, on the other hand, may include re-reading key points, skimming through the text or summarizing the passage. He further comments that good readers continue to reflect the meaning of a text long after they read it.

A more comprehensive classification of reading strategies has been offered by Zhang (1993) who divides reading comprehension strategies into four general categories: cognitive strategies, compensation strategies, memory strategies and test-taking strategies.

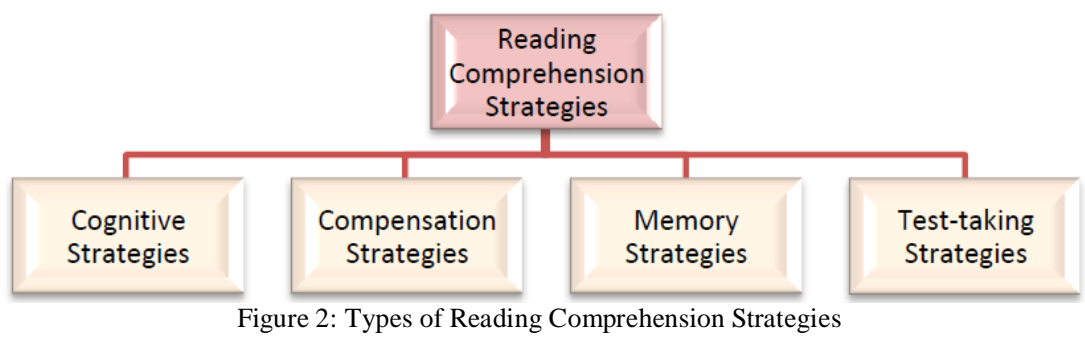

\section{Cognitive Strategies}

Reading comprehension is a cognitive process requiring different cognitive strategies. These strategies include using prior knowledge, previewing, predicting and self-questioning etc.

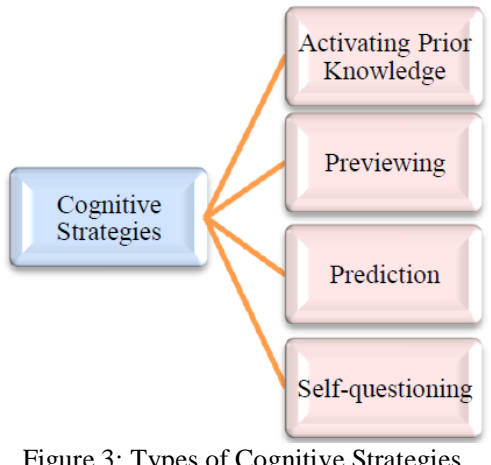

\section{a. Activating Prior Knowledge}

Activating prior knowledge means making connections between the new and the known. The concept of prior knowledge is based upon Schema theory. The basic assumption in this theory is that new information is learnt by connecting it with one's previously learnt information to construct meaning. The information which one already has is called prior knowledge or schemata (plural of schema). Nuttall (1996) informs that the schema is an abstract structure in the mind. This structure is organized of all of the experiences a person ever had. In the context of reading, schemata refer to conceptual understanding, experiences, attitudes, values, and skills a reader brings to a text situation. Research has strongly supported that schemata or prior knowledge has a positive correlation with reading comprehension. For instance, Vacca (2002) affirms that readers are in a better position to comprehend what they are reading whenever they use prior knowledge (schemata) to construct meaning. Likewise, Rauch and Weinstein (1968) claim that prior knowledge or experience enables the reader to pursue the text meanings effectively.

\section{b. Previewing}


Previewing means 'guessing before reading'. It is a very quick technique to find out where the required information is likely to be (Grellet, 1996, p. 17- 18). It involves using the title of a text, figures, graphs, charts, diagrams, the table of contents, the index, the appendices, the preface of the author or publisher, headings or subtitles of chapters and paragraphs, information in the back cover etc. By using these clues, good readers make guesses about what a text may be about. Rahman (2007) states that this skill saves students' time by helping them to search out intended and specific information within a few minutes.

\section{c. Prediction}

Prediction means guessing while reading. Predicting involves thinking ahead while reading, and anticipating information and events in the text (Grellet, 1996). Hedge (1985) proposes that a successful reading does not require going through each and every line in the text. Instead, the readers depend largely on the prediction from the syntactic and semantic clues and their previous knowledge.

\section{d. Self-Questioning}

Self-questioning means interrogating oneself about the text during and after reading for different purposes such as checking one's own understanding of the text, querying about author's point, and making connections and relationships among ideas and information within the text. Vacca (2002) asserts that skilled readers are prompted to self-question when they notice important points or come across a host of different ideas in the text in order to understand their implicit, logical relationships contributing to the whole meaning.

\section{Compensation Strategies}

Compensation strategies may be defined as the strategies the readers use to compensate any difficulty or confusion they encounter in the way of getting meanings out of a text (Zhang, 1993).

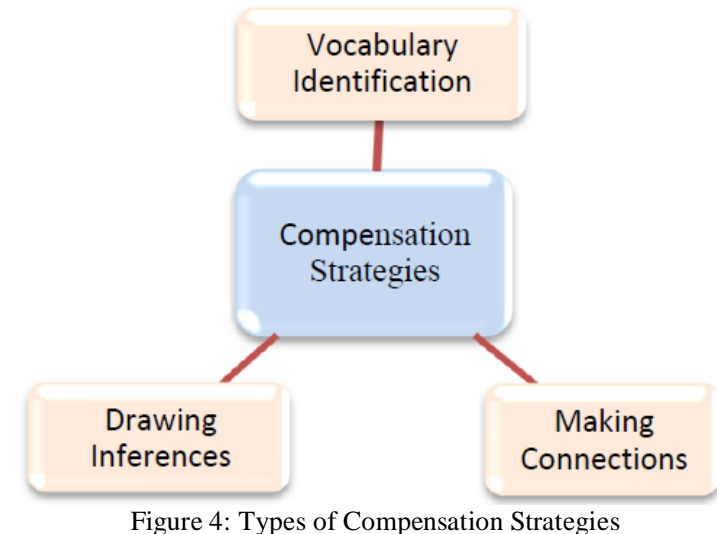

a. Vocabulary identification: knowing how words work

Studies conducted on the importance of vocabulary instruction demonstrate that there is a direct link between vocabulary development and reading comprehension and that it plays a major role in improving comprehension. Zhang (1993:6) opines, "One problem encountered by many readers is unfamiliar vocabulary and unknown concepts. This is where the reader needs to use compensation strategies to arrive at comprehension". There are various types of vocabulary comprehension skills such as using context clues, recognizing words with multiple meanings, understanding connotative and denotative meanings, using part of speech for meaning and sing personal experiences and background knowledge (schemata)

\section{b. Drawing Inferences}

Making inference means filling in the gaps left by the author. This implies realizing unstated statements of the author, or linking different segments which the writer did not link explicitly. Rahman (2007) states that sometimes, the writers suggest something indirectly instead of stating it directly through words. So, it becomes "the responsibility of the readers to infer this information" (p. 44). Inferencing is also known as 'reading between the lines'.

\section{c. Making Connections}

This strategy is referred to as reading beyond the lines. Through this strategy reader looks the currently got information of the target text in the light of his previous life experiences, other texts he ever read before, and cultural and global matters to enrich the meanings and deepen the understanding of what the author says.

\section{Memory Strategies}

Memory strategies include the techniques which help to memorize, store and retain the details of a text. 


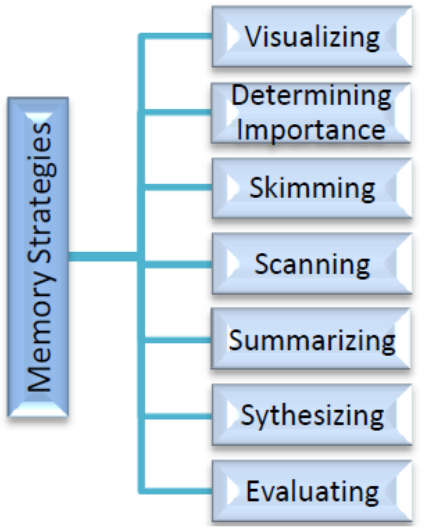

Figure 5: Types of Memory Strategies

\section{a. Visualizing/Creating Mental Images}

Visualizing refers to forming mental and visual images of the textual content. There is an old saying that a picture is worth a thousand words. When it comes to comprehension, this saying might be paraphrased, 'a visual display helps readers understand, organize, and remember some of those thousand words' (Duke \& Pearson, 2002). Visual representation causes the textual information to retain in memory for a longer time.

\section{b. Determining Importance}

This strategy involves distinguishing important details from the unimportant ones. It helps students to identify explicit and implicit ideas, extract the essence of the text, give a conceptual summary and realize relevance of ideas and information which facilitate memory and, subsequently, comprehension of the text.

\section{c. Skimming}

Grellet (1996, p. 4) and Urquhart and Weir (1998, p. 102) define skimming as 'reading for gist'. According to Williams (1996), the purpose of skimming is "simply to see what a text is about. The reader skims in order to satisfy a very general curiosity about the text, and not to find the answer to particular questions." (p. 96-97). Experts have given much importance to skimming as a reading strategy. For example, Rayner and Pollatsek (1989) argue that people have to confront too many books with multiplicity of meanings and variety of information. In such situations, skimming facilitates them by saving their time.

\section{d. Scanning}

Scanning refers to reading a text in order to find out a particular piece of information. Williams (1996, p. 107) defines scanning as "reading for particular points". In Nuttall's (1996) opinion, scanning is "glancing rapidly through a text either to search for a specific piece of information".

\section{e. Summarizing}

Summary means short, coherent and cohesive description of the essential ideas of a text. It is a written or spoken statement of the main points and their relation to each other. It is usually very short, so it must include only the most important ideas. Research suggests that instruction and practice in summarizing not only improves students' ability to summarize text, but also their overall comprehension of text content (Duke \& Pearson, 2002).

\section{f. Synthesizing Information}

Synthesis involves making ideas of the text go together in new patterns, rearranging textual information and combining it with the information from different sources in a way that new learning fits together with the old learning resulting in coherent unique patterns..

\section{g. Evaluating}

Evaluation means live interaction with the text. It might refer to checking probability or improbability of the text in the light of one's prior knowledge and understanding of the world. It also refers to thinking about author's or characters' value judgments, and allows readers to agree or disagree with the author's point.

\section{Test-Taking Strategies}

The type of strategies which readers require to perform well in the various tests of reading comprehension and recall are called test taking strategies. Researchers have recommended a number of test taking strategies. Most of the studies are related with multiple choice items in standardized tests. Pearson and Johnson (1978) based their study on question types and corresponding question-answering strategies. Their findings identified three types of questions and corresponding locations for their answers:

- Textually explicit questions whose answers can be located in the text directly on the lines.

- Textually implicit questions whose answers can be located between the lines.

- Scriptally implicit questions whose answers can only be generated beyond the lines.

Zhang (1993, p. 11) presents two test taking strategies as recommended by Jacobs (1985), Oxford (1990) and Zhang (1992). The first strategy is that before reading a passage, the test taker should first read questions and answers. This will help the reader focus on the relevant information in the text. Secondly, the test taker should answer each question 
by the process of elimination for multiple choice questions. These strategies may improve their reading efficiency and test results.

Having analyzed the nature of all types of reading strategies, the researchers have been able to sketch a model of the types of reading strategies with a view to Pressley \& Wharton-McDonald's (1997) and Rice's (2009) classification, i.e. before reading, while reading and post reading strategies. The researchers' proposed model is presented below:

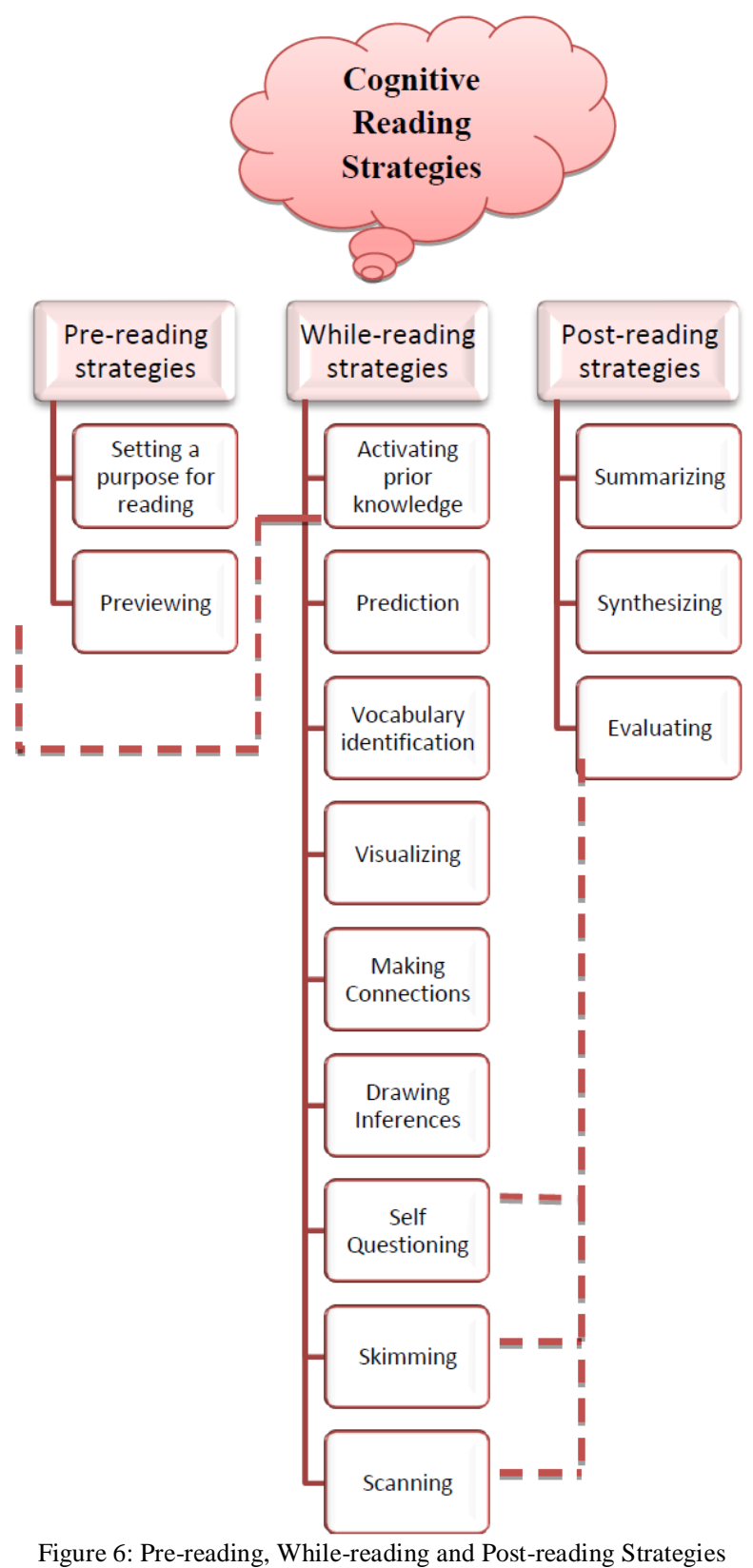

\section{E. Reading Strategy Instruction}

At present, research has started focusing on whether it is possible to improve learners' comprehension through comprehension strategy instruction. Many studies have shown that reading strategies can be taught to students, and when taught, strategies help improve students' performance on tests of comprehension and recall (Carrell, 1985; Brown \& Palincsar, 1989; Carrell, et al., 1989; Pearson \& Fielding, 1991 cited in Song, 1998). Research on reading strategies instruction is available both in L1 and L2 context. Both of the contexts have demonstrated that reading strategies can be taught to students, and that they can bring improvement in their reading proficiency. For example, in one of the studies, Brown and Palincsar (1984) gave individual training of four concrete reading strategies (summarizing, questioning, clarifying, and predicting) to $7^{\text {th }}$ grade native speakers of English outside the classroom setting. They found that the strategy training effectively enhanced native English speakers' reading ability. Later, in an attempt to identify the implications of Brown and Palincsar's (1984) study in an EFL context, Song (1998) investigated the impact of Brown and Palincsar's (1984) strategy training on the reading ability of EFL university students in classroom settings. The 
results disclosed that the reading strategy training does improve EFL students' reading proficiency, In the same stratum, Baier (2005) conducted a research on fourteen sixth grade L2 learners who underwent a six week long study of SelfQuestioning Reading Strategy; the study was based upon explicit instruction. A comparison of students' reading comprehension pre-test and post-test scores revealed an overall improvement in their reading comprehension.

With an eye to the aforementioned studies depicting the impact of reading strategies instruction on reading comprehension ability of L1 and L2 learners, the researchers ventured to undertake the study on L2 reading skills in the region of southern Punjab in Pakistan. This study was planned to investigate and highlight the nature of relationship between reading strategies instruction and learners' proficiency in ESL text comprehension. Henceforth, the following methodology was designed by the researchers.

\section{RESEARCH METHODOLOGY}

The study is based upon both quantitative and qualitative methods of data collection and analysis. Being correlational in its nature and type, the study employed correlational paradigms, but these paradigms were initially ascertained through descriptive means of investigation. The variables involved were surveyed, analyzed and described in terms of the extent, measure and frequency of their existence in the target population, which in turn paved way for identifying correlations among them. These correlations were recognized through applying standard correlational tests on the variables involved.

\section{A. Research Site and Participants}

The study was conducted at the department of English, The Islamia University of Bahawalpur, which formulates the basic site for data collection and implementation of the results obtained through the present research. The focus of the study was reading comprehension skills taught and learnt in ELT context in the above mentioned research site. The research sample consisted of 40 students taken as 'participants' in the present research context. The participants were selected randomly from B.A Hons classes $\left(3^{\text {rd }}, 5^{\text {th }}\right.$, and $7^{\text {th }}$ semesters $)$ of the department of English, The Islamia University of Bahawalpur. The participants' consent and voluntary willingness to participate in the research was especially considered during their selection as research participants. The participants comprised of both male and female students.

\section{B. Data Collection Tools}

A questionnaire and a critical reading test were used as data collection tools.

\section{Questionnaire}

Students' questionnaire was aimed at assessing their teachers' use of different types of reading strategies instruction while teaching reading skills to ESL learners (participants). The questionnaire included 33 items whose responses were developed in terms of 5-point likert scale depicting frequency of use i.e. never, rarely, sometimes, often and always. Each of the items asked how often a particular reading strategy was used by the participants' teachers as a part of their reading instruction. The items were confined to reading comprehension strategy instruction only, as the aspects related to correct pronunciation, repeated reading, silent and loud reading or fluency and speed in reading have not been dealt with in the present research. For an ease of understanding and analysis on the part of the participants and researcher respectively, the items in the questionnaire were divided into three sections, i.e. pre-reading, while reading and postreading strategies based upon the model presented by the researchers in figure 6 (pg. 12). This was basically a selfdesigned questionnaire. However, a few of the items $(1,3,6,8,11,12,19,20,21,22,23,25$ and 28) were adopted from Rahman (2007) and rephrased to suit questionnaire's design and structure. The questionnaire consisted of three parts: pre-reading, while-reading and post-reading. The three parts inquire different types of strategies instruction practiced by the participants' teachers in their pre-reading, while-reading and post-reading teaching sessions respectively.

\section{Reading Comprehension Test}

The reading comprehension test was designed to check participants' reading comprehension ability. It consisted of a passage containing 5 paragraphs. The respondents were asked to write answers to the 14 questions given at the end of the passage.

\section{Data ANALYSis AND Findings}

The study employed both quantitative and qualitative methods for data analysis and its interpretation. The questionnaire, being quantitative in nature, was analyzed statistically by using Statistical Package for Social Sciences (SPSS) software. The reading comprehension test, being qualitative in nature, was first marked and graded. Then the attained results were quantified and statistically computed by submitting the participants' achieved scores for each item to SPSS followed by their interpretation. The results of the two tools were compared and contrasted in the light of the formulated research questions and presented in the form of tables, charts, graphs and figures. The findings associated with each instrument were first discussed through descriptive statistics followed by the identification of correlations among different key as well as sub-variables (factors). Following the statistical trends and rules, the explored correlations were then depicted through scatter plots and charts. 


\section{A. Analysis of Questionnaire: Measurement of Reading Strategy Instruction}

The level of reading strategy instruction was measured through students' questionnaire. The level of provided instruction was characterized as 'very high', 'high', 'medium', 'low' and 'very low' in accordance with the frequency of the participants' answers in response to each question on the 5-point likert scale (Never, Rarely, Sometimes, Often, Always) given in the questionnaire. A very high level of reading strategy instruction was identified for mean score 4.0 or higher; high level of instruction was regarded for mean score 3.5 or higher but lower than 4.0; medium level of instruction was recognized for mean score 2.5 to 3.4; low level of reading strategy instruction was considered for mean score 2.0 to 2.4 ; and very low instruction was regarded for mean score 1.9 or lower. The key for interpretation is being presented in tabulated form below:

TABLE 1:

KEY TO MEASURE THE LEVEL OF READING STRATEGY INSTRUCTION

\begin{tabular}{ll}
\hline Mean Score & Level of Reading Instruction \\
\hline $1.0-1.9$ & Very low \\
$2.0-2.4$ & Low \\
$2.5-3.4$ & Medium \\
$3.5-3.9$ & High \\
$4.0-5.0$ & Very high \\
\hline
\end{tabular}

\section{Measurement of Pre-Reading Strategy Instruction}

The first section of the questionnaire was meant to measure the level of pre-reading strategy instruction provided to the participants. The following statistics were computed for this section:

TABLE 2:

DESCRIPTIVE STATISTICS FOR PRE-READING STRATEGY INSTRUCTION

\begin{tabular}{lllll}
\hline No. & Item Description & N & $\begin{array}{c}\text { Mean } \\
\text { Standard } \\
\text { Deviation }\end{array}$ \\
\hline 1 & Dividing Reading Lesson & 35 & 3.69 & 1.301 \\
2 & Asking Warm-up Questions Before Reading & 35 & 4.51 & .853 \\
3 & Explaining the Background of the Text & 35 & 4.94 & .236 \\
4 & Setting a Specific Purpose for Students' Reading & 35 & 4.31 & .832 \\
5 & Predicting Text Through Titles & 35 & 4.71 & .519 \\
6 & Interpreting Graphics, Charts, Maps and Tables & 35 & 4.06 & .998 \\
\hline
\end{tabular}

As the data exhibits, the mean score for item 1 is 3.69 (high--- $M>3.5$ ) while the mean scores for items 2, 3, 4, 5 and 6 are found to be 4.51, 4.94, 4.31, 4.71 and 4.06 respectively (very high--- $M>4.0$ in each case) which shows that the participants' teachers are very much concerned with practicing pre-reading teaching techniques in their language classroom. They frequently ask warm up questions before starting their reading lesson, explain background of the text and set a purpose for students' reading. They also make their students predict titles and interpret graphics, charts, tables and maps. The overall results show that a very high level of pre-reading strategy instruction (i.e. M= or higher than 4.0) is available to the students.

\section{Measurement of Reading Strategy Instruction}

The second section of the questionnaire comprised of 17 items of while-reading strategy instruction. The following results were calculated for this section:

TABLE 3:

DESCRIPTIVE STATISTICS FOR READING STRATEGY INSTRUCTION

\begin{tabular}{lllll}
\multicolumn{1}{c}{ DESCRIPTIVE STATISTICS FOR READING STRATEGY INSTRUCTION } & N & $\begin{array}{c}\text { Mean } \\
\text { Standard } \\
\text { Deviation }\end{array}$ \\
\hline 7 & Item Description & 35 & 4.34 & .802 \\
8 & Reading a Text with a Set Purpose & 35 & 4.46 & .886 \\
9 & Using Prior Knowledge and Experience to Understand Text & 35 & 1.200 \\
10 & Making Guesses About Upcoming Information & 35 & 4.11 & .867 \\
11 & Self-questioning during Reading & 35 & 4.66 & .482 \\
12 & Guessing the Meaning of Unfamiliar Words & 35 & .622 \\
13 & Inferring the Unstated Statement of the Writer & 3.71 & 1.163 \\
14 & Visualizing the Content of the Text & 35 & .796 \\
15 & Teaching How to Use Visual Organizers & 35 & 4.31 & 1.382 \\
16 & Re-reading Text on Conflicting Information & 35 & 4.03 & .482 \\
17 & Underlining Key-Words and Phrases & 35 & 4.66 & .514 \\
18 & Taking Important Notes While Reading & 35 & 4.83 & .765 \\
19 & Surveying Text Organization & 35 & 4.66 & .804 \\
20 & Skimming Through a Text & 35 & 4.00 & .741 \\
21 & Scanning a Text & 35 & 4.54 & .980 \\
22 & Reading Text Intensively & 35 & 4.26 & .739 \\
23 & Reading Text Extensively & 35 & 4.57 & .951 \\
\hline
\end{tabular}


The above given statistics demonstrate that the ESL learners are exposed to a very high level (M= or higher than 4.00 in case of each variable) of While-Reading Strategy Instruction. It implies that the teachers almost always instructed their students about reading text with a set purpose in mind $(\mathrm{M}=4.34)$, using prior knowledge and experience to understand text $(\mathrm{M}=4.46)$, making guesses about upcoming information in the text $(\mathrm{M}=4.17)$, self-questioning during reading $(M=4.11)$, guessing the meaning of unfamiliar words and phrases $(M=4.66)$, consulting reference materials $(M=4.71)$, inferring the instated statement of the author $(M=4.00)$, visualizing the content of the written text $(M=$ 4.31) and using various visual organizers $(M=4.03)$. Moreover, these teachers very frequently made their students reread text on conflicting information $(M=4.66)$, underline key words and phrases $(M=4.83)$ and take important notes while reading $(M=4.66)$. They also very often taught their students how to survey text organization $(M=4.00)$, how to skim through a text $(M=4.54)$, how to scan a text $(M=4.26)$, how to read text intensively $(M=4.57)$ or extensively $(\mathrm{M}=4.09)$. The average mean score for total while-reading strategy instruction came out to be 4.38 , i.e. very high.

\section{Measurement of Post-Reading Strategy Instruction}

The third section of the questionnaire aimed to assess post-reading teaching techniques used by ESL teachers of the said population. The following table displays the statistics calculated for this section:

TABLE 4:

DESCRIPTIVE STATISTICS FOR POST READING STRATEGy INSTRUCTION

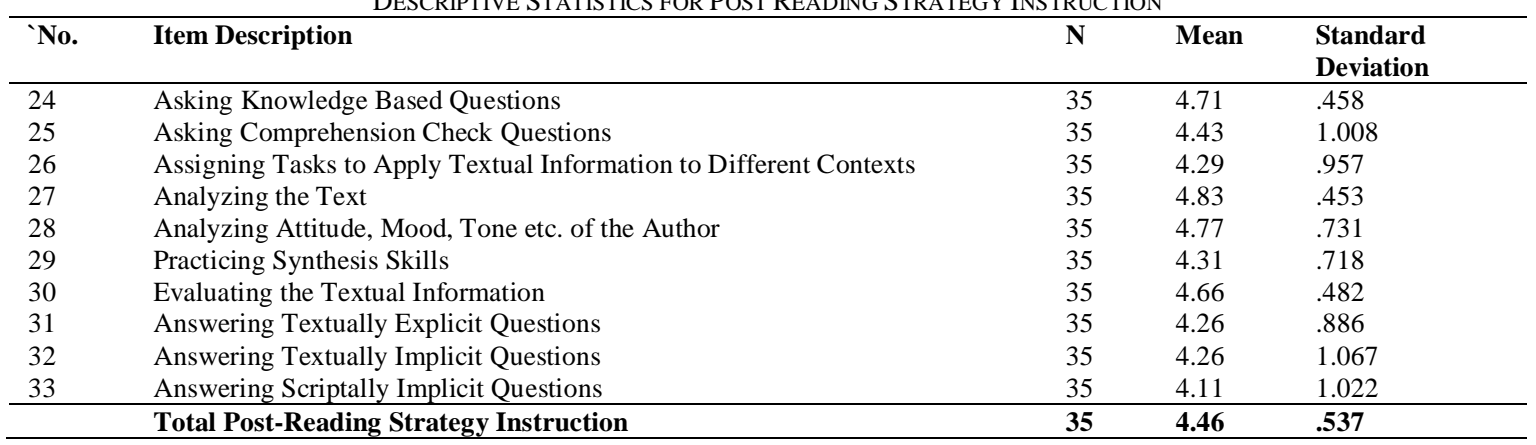

In the light of the participants' responses to section 3, as the above data shows, all of the post-reading teaching techniques are found to be in much vogue among ESL teachers of the said population. The total mean score (4.46) implies that a very high level of post-reading strategy instruction $(\mathrm{M}=$ or $>4.0)$ is practiced by the participants' teachers in their language classroom. To talk about the individual items, their Mean scores are described here:

For item 24 (Does your teacher teach you knowledge based question?) the Mean score is 4.71 (very high), for item 25 (Does your teacher ask you comprehension check questions?) the Mean score is 4.43 (very high), for item 26 (Does your teacher assign you tasks to apply textual information to some different given contexts?) the Mean score is 4.29 (very high), for item 27 (Does your teacher teach you how to analyze text?), the Mean score is 4.83 (very high), for item 28 (Does your teacher teach you how to analyze attitude, mood, tone etc. of the author?) the Mean score is 4.77 (very high), for item 29 (Does your teacher help you practice synthesis skills?) the Mean score is 4.31 (very high), for item 30 (Does your teacher encourage you to evaluate textual information?) the Mean score is 4.66 (very high), for items 31 (Does your teacher teach you how to answer textually explicit questions?) and 32 (Does your teacher teach you how to answer textually implicit questions?) both, the Mean score is 4.26 (very high), and for item 33 (Does your teacher teach you how to answer scriptally implicit questions?) the Mean score is 4.11 (very high).

\section{Comparison of the Three Types of Reading Instruction}

The results obtained through descriptive statistics of the questionnaire indicate that post-reading strategy instruction $(\mathrm{M}=4.46)$ is more frequently used than any of the other two types of instruction, i.e. pre-reading $(\mathrm{M}=4.37)$ and reading strategy instruction $(\mathrm{M}=4.38)$. This can be shown in the form of a chart as follows:

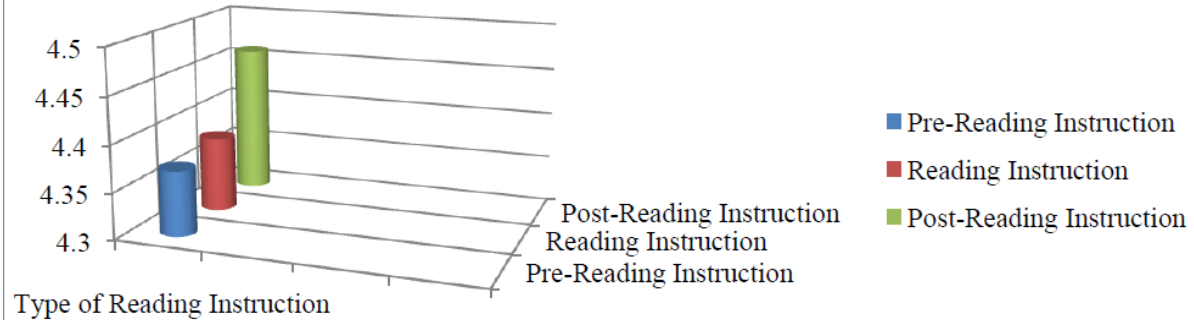

Chart 1: Comparative Scores for Types of Reading Strategy Instruction

Finally, scores for overall reading strategy instruction were calculated which are presented in tabulated form below: 
TABLE 5:

DESCRIPTIVE STATISTICS FOR OVERALL READING STRATEGY INSTRUCTION

\begin{tabular}{llll}
\hline Variable Description & N & Mean & Standard Deviation \\
\hline Total Reading Strategy Instruction & 35 & 4.4017 & .41193 \\
\hline
\end{tabular}

The average mean score (4.40) illustrates that on the whole, a very high level of reading strategy instruction is being practiced by the teachers in their ESL classroom.

\section{B. Analysis of Reading Comprehension Test}

After its due marking by the researcher, the results of the reading comprehension test were calculated in the form of percentages and their corresponding grades. The following key was used for interpretation of the participants' marks in reading comprehension test.

TABLE 6:

KEY FOR INTERPRETATION OF THE RESULTS OF READING COMPREHENSION TEST

\begin{tabular}{llll}
\multicolumn{4}{c}{ KEY FOR INTERPRETATION OF THE RESULTS OF READING COMPREHENSION TEST } \\
\hline Sr. No. & $\%$ Marks & Grade & Remarks \\
\hline 1 & $90 \%$ or above & A+ & Marvelous/Exceptional \\
2 & $80 \%-89 \%$ & A & Excellent \\
3 & $70 \%-79 \%$ & B+ & Very Good \\
4 & $60 \%-69 \%$ & B & Good \\
5 & $50 \%-59 \%$ & C & Fair \\
6 & $40 \%-49 \%$ & D & Satisfactory \\
7 & Below $40 \%$ & F & Poor \\
\hline
\end{tabular}

In the light of the above interpretation key, the following data was attained for overall results of the reading comprehension test:

TABLE 7:

OVERALL RESULTS OF THE READING COMPREHENSION TEST

\begin{tabular}{lllll}
\hline Sr. No & $\%$ Marks & Grade & Frequency & Frequency $\%$ \\
\hline 1 & $90 \% \&$ above & A+ & 17 & $49 \%$ \\
2 & $80 \%-89 \%$ & A & 13 & $37 \%$ \\
3 & $70 \%-79 \%$ & B + & 4 & $11 \%$ \\
4 & $60 \%-69 \%$ & B & 1 & $3 \%$ \\
5 & $50 \%-59 \%$ & C & 0 & $0 \%$ \\
6 & $40 \%-49 \%$ & D & 0 & $0 \%$ \\
7 & Below 40\% & F & 0 & $0 \%$ \\
\hline
\end{tabular}

The results reveal that $49 \%$ of the students passed the Reading Comprehension Test with A+ grade (Marvelous/Exceptional), 37\% of them got A grade (Excellent), 11\% secured B+ grade (Very Good) and the remaining $3 \%$ of the participants achieved B grade (Good). None of the participants got C (Fair), D (Satisfactory) or F grade (Poor). The top highest (49\%) and the second highest percentage (37\%) of participants securing A+ and A grades respectively is demonstrative of the fact that students' overall reading comprehension proficiency is excellent. The percentage of students' achieved grades in the said test can be depicted in the form of a pie chart given below:

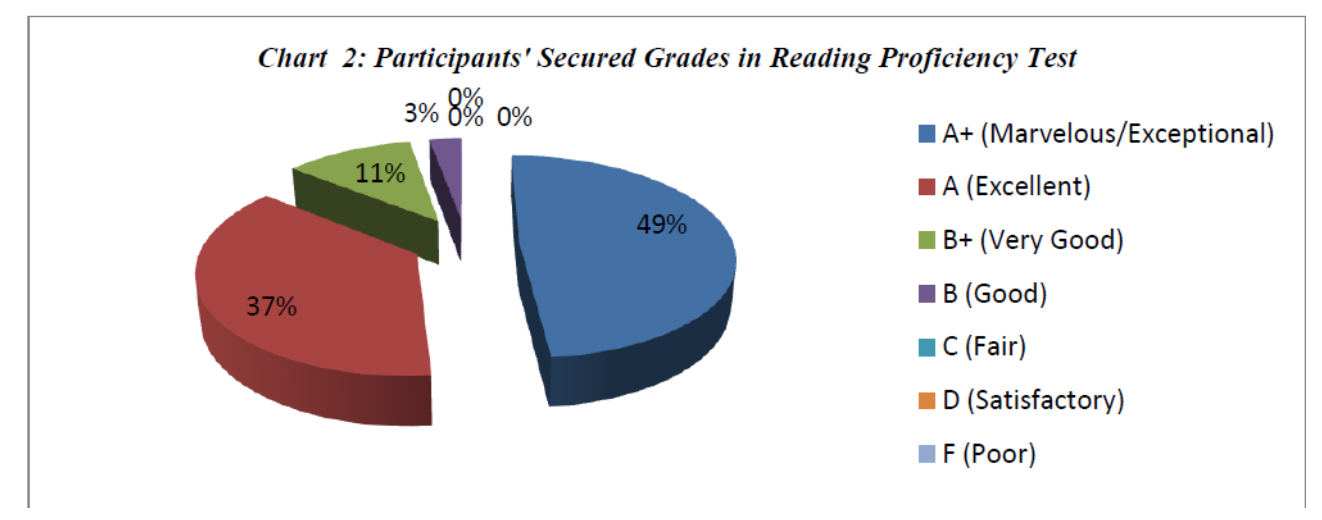

It is evident from the above data that the participants' showed a very high level of proficiency in text comprehension.

\section{Correlation between Reading Strategy Instruction and Reading Comprehension Proficiency}

Pearson Product-moment correlation coefficients were computed to investigate the statistical relationship between Reading Strategy Instruction and Proficiency in L2 text comprehension. 
TABLE 8:

RESULTS OF PEARSON PRODUCT-MOMENT CORRELATION FOR READING INSTRUCTION AND PROFICIENCY IN TEXT COMPREHENSION

\begin{tabular}{|c|c|c|c|}
\hline & & $\begin{array}{l}\text { Reading Strategy } \\
\text { Instruction }\end{array}$ & $\begin{array}{l}\text { Proficiency in Reading } \\
\text { Comprehension }\end{array}$ \\
\hline \multirow{3}{*}{$\begin{array}{l}\text { Reading Strategy } \\
\text { Instruction }\end{array}$} & Pearson Correlation & 1 & $.977^{* *}$ \\
\hline & Sig. (2-tailed) & & .000 \\
\hline & $\mathrm{N}$ & 35 & 35 \\
\hline \multirow{3}{*}{$\begin{array}{l}\text { Proficiency in Reading } \\
\text { Comprehension }\end{array}$} & Pearson Correlation & $.977^{* * \pi}$ & 1 \\
\hline & Sig. (2-tailed) & .000 & \\
\hline & $\mathrm{N}$ & 35 & 35 \\
\hline
\end{tabular}

The results communicate that a strong positive correlation exists between reading strategy instruction $(r=.977, p$ $=.000)$ and reading comprehension proficiency. The correlation is significant at the level 0.01. The visual representation of this type of correlation is produced in chart 4.9:

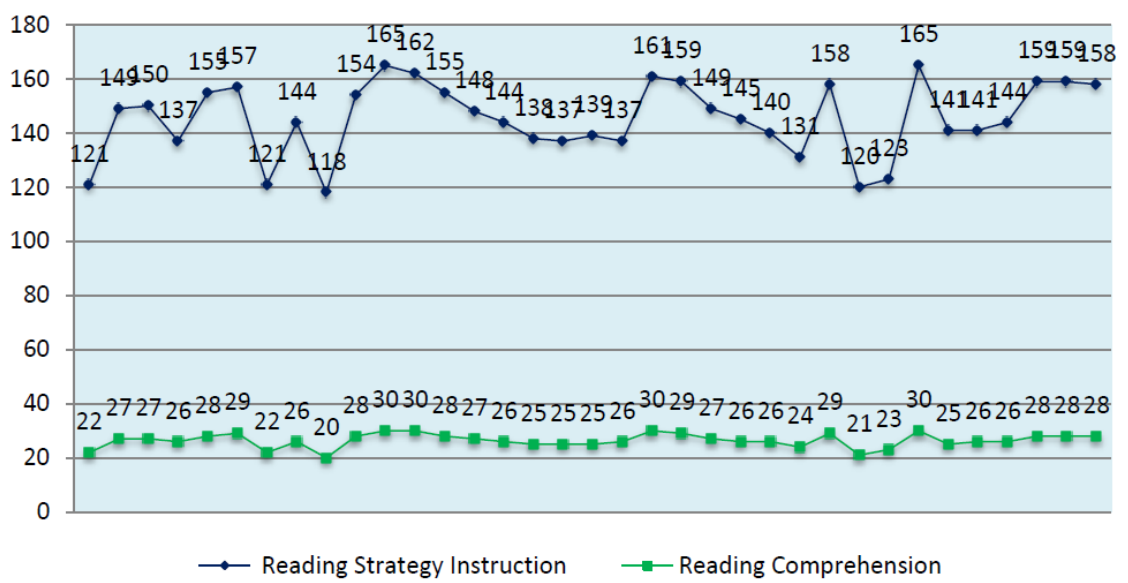

Chart 3: Scatter Plot for Correlation between Reading Strategy Instruction and Reading Comprehension Proficiency.

The strong similarity in the vertical flow of points in each category is supportive of a positive relationship.

\section{Determination of Correlations among Different Factor Variables}

Having explored the correlations among basic/key variables, the researchers conducted zero order correlations for the sub-variables which are the factors of the major or key variables. Reading instruction has three factor variables: prereading instruction, while-reading instruction and post-reading instruction.

TABLE 9:

RESULTS OF PEARSON PRODUCT-MOMENT CORRELATIONS FOR FACTOR VARIABLES

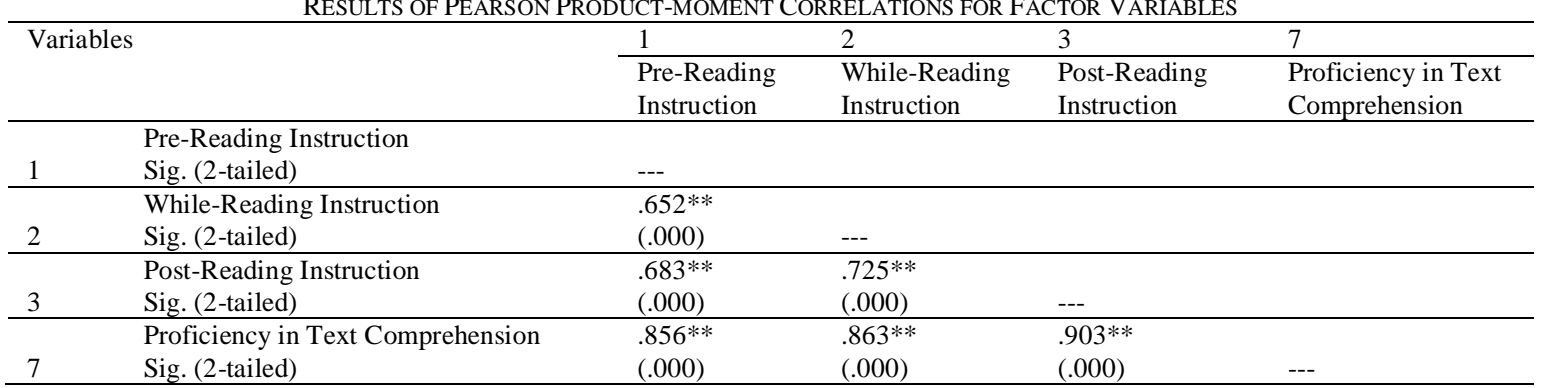

Through the examination of the above table, it is declared that a very strong positive relationship exists between prereading and while-reading instruction $(r=.652, p=.000)$, between pre-reading and post-reading Instruction $(r=.683, p$ $=.000)$, and between while-reading and post-reading instruction $(r=.725, p=.000)$. Pre-reading instruction has also got a very strong positive correlation with reading comprehension ability $(r=.856, p=.000)$. Almost same is the case with post-reading instruction which has disclosed a very strong relationship with reading proficiency $(r=.903, p$ $=.000)$. Similarly, reading strategy instruction has also shown a very strong relationship with reading proficiency $(r$ $=.863, p=.000)$.

\section{DisCUSSION AND CONCLUSION}

- With regard to the teachers, the results of the present study have proposed a very hopeful situation. A very satisfactory level of reading strategy instruction is observed being practiced by the teachers of English department at 
The Islamia University of Bahawalpur. This suggests that the ESL teachers of the said institute efficiently instruct their learners about the use of various types of pre-reading, while-reading and post-reading strategies in their reading tasks.

- The results of reading comprehension test have also displayed almost an ideal type of linguistic scenario with respect to ESL learners' proficiency in reading comprehension. This stands in controversy to the claims put forward by a number of other researchers in response to their studies contextualized inside or outside Pakistan. For example, Grabe (1991), who believes that reading is the most important skill for L2 learning, claims that in Asian countries students obtaining the higher level studies lack sufficient reading skills. The present study has disclosed that this claim does not stand valid at least in the context of the L2 learners of The Islamia University of Bahawalpur, as it is found that ESL learners of English department at this institute are highly proficient in text comprehension.

- A very strong positive correlation $(\mathrm{r}=.977 * *)$ between reading strategy instruction and proficiency in text comprehension suggests that the more the reading strategy instruction, the better the proficiency in text comprehension. With a view to the found correlation, it can be proposed that learners' high level of proficiency in text comprehension might be the outcome of reading strategy instruction or training being provided to them by their teachers.

- The strong positive correlation between pre-reading and while-reading instruction, between pre-reading and postreading instruction, and between while-reading and post-reading instruction proves the interdependence of all types of reading strategies. This implies that using pre-reading strategies might automatically facilitate the use of reading or post reading strategies, and for using post reading strategies the reader might naturally need to depend upon pre-reading or while reading strategies and so on.

- A very strong positive correlation between each type of reading strategy instruction (i.e. pre-reading, while-reading and post-reading instruction) and reading proficiency also depicts the interrelationship between each type of reading strategy and reading proficiency.

The findings of the present paper stand in layer with Brown and Palincsar's (1984) studies which had experimentally proved that native English speakers' reading ability can be improved through direct instruction of reading strategies. The same was inferred through Song's (1998) implications of Brown and Palincsar's (1984) study on non-native English speakers in classroom settings. Moreover, Bair (2005) had also shown that explicit instruction of reading strategies can enhance reading performance.

\section{RECOMMENDATIONS}

At the end, the study reveals that making ESL learners proficient in reading comprehension skills is not as difficult a task as it is considered to be. What is needed is to provide an explicit reading strategies instruction to them. The findings of the study have also demonstrated that the quality of teaching and learning of reading comprehension skills in English department at The Islamia University of Bahawalpur is admirable. The teachers are teaching various kinds of reading strategies to the learners and the learners are highly proficient in reading comprehension.

In this particular scenario, following recommendations can be put forward to improve the quality of ESL reading as a basic part of ESL teaching and learning.

- The teachers should teach all types of reading strategies (cognitive strategies, memory strategies, compensation strategies and test taking strategies) to their students. They should assign them various reading tasks both inside and outside classroom settings in order to provide them opportunities to practically apply these strategies in reading.

- The teachers should have a thorough knowledge of all possible types of reading strategies and also about how, when, where and why to use these strategies. This is essential for the teachers in order to be able to practice such knowledge properly in their reading instruction. Here teacher training programs can be helpful.

- The students should be provided a direct and explicit instruction about the nature and use of reading strategies. During their reading lessons they should consciously be made aware of the titles and the effectiveness of the strategies being used at various stages of the lesson. In any reading lesson, everything at the instruction (i.e. presentation), practice and production stages should be made explicit, direct and obvious to the students.

- Instruction and practice of reading strategies should be provided and implemented to such an extent that the students automatically become independent readers and be able to select and use the appropriate strategies at appropriate places quite independently during their reading tasks. This can be carried out firstly by teaching them various reading strategies and then, assigning them reading comprehension tasks in the classroom with certain predefined reading purpose. Once they complete their reading task, the teacher should ask them what strategies they used while reading, and where, when, why and how they used such strategies.

\section{SUGGESTIONS FOR FURTHER RESEARCH}

The present research investigated the teaching and learning practices and implications of ESL reading comprehension skills in The Islamia University of Bahawalpur. So the results obtained should better be generalized only to the university level institutes and their relevant population alone. If the data were collected from college students instead of university graduates of Bahawalpur, the findings might not necessarily have been the same. This probability paves ground for a further research which should aim to investigate the status of and approaches to teaching and learning practices of reading comprehension skills in degree colleges of Bahawalpur, and hence to expose if there exists any 
differences in the current practices of reading comprehension skills among college and university institutes, and that in case there exists any such difference, what are their causes.

Moreover, a great number of researches in Pakistan have explored and determined the differences between educational practices of the government and those of the private institutes in different aspects of Language teaching. The same can be carried out in the matter of ESL reading comprehension skills. The proposed research in this context should be comparative in nature. This research would aim to compare or contrast the state of and approaches to teaching and learning of reading comprehension skills in both private and government institutes of Bahawalpur or any other district in Pakistan. The explored comparisons might lead to various theoretical, descriptive, practical and suggestive results in favour of promoting better ESL reading comprehension skills in Pakistan.

\section{REFERENCES}

[1] Adler, C.R. (2001). Put Reading First: The Research Building Blocks for Teaching Children to Read, pp. 49-54. National Institute for $\quad$ Literacy. $\quad$ Retrieved Nov. 1, 2012, from http://www.nifl.gov/partnershipforreading/publications/reading_first 1 text.html.

[2] Baier, J. R. (2005). Reading comprehension and reading strategies: A Research Paper Submitted in Partial Fulfillment of the Requirements for the Master of Education Degree in Education. The Graduate School: University of Wisconsin-Stout.

[3] Brown, A., \& Palincsar, A. (1984). Reciprocal Teaching of Comprehension-Fostering and Comprehension Monitoring Activities. Cognition and Instruction, 1(2), 117-175.

[4] Dechant, E.V. (1982). Improving the Teaching of Reading. New Jersey: Prentice-Hall, Inc.

[5] Duke, N. K. \& Pearson, D. (2002). Effective Practices for Developing Reading Comprehension. In A.E. Farstrup \& S.J. Samuels (Eds.). What Research Has To Say About Reading Instruction (3rd ed., pp. 205-242). Newark, DE: International Reading Association.

[6] Eskey, D. E. (2002). Reading and the Teaching of L2 Reading, TESOL Journal, 2002, 11(1), 5-9.

[7] Grellet, F. (1996). Developing Reading Skills: A Practical Guide to Reading Comprehension Exercises. Cambridge University Press.

[8] Hedge, T. (1985). Using Readers in Language Teaching. London: Macmillan.

[9] Jacobs, M. L. (1985). GED Scoreboosters 2. Toronto, Canada: Steck Vaugn Company.

[10] Mikulecky, B. S. (2008). Teaching Reading in a Second Language. Available from: http://www.longmanhomeusa.com/content/FINAL-LO\%20RES-Mikulecky-Reading\%20Monograph\%20.pdf.

[11] Nuttall, C. 1996. Teaching Reading Skills in a foreign language. Oxford: Heinemann.

[12] Oxford, R. L. (1990). Language Learning Strategies: What Every Teacher Should Know. New York: Newbury House Publishers.

[13] Pearson, P. D. and Johnson, D. D. (1978). Teaching Reading Comprehension. New York. New York: Holt, Rinehart and Winston.

[14] Pressley, M. \& Wharton-McDonald, R. (1997). Skilled Comprehension and its Development through Instruction. School Psychology Review, 26, 448-466.

[15] Rahman, Md. H. (2007). An Evaluation of the Teaching of Reading Skills of English in Bangladesh. A thesis submitted in partial fulfillment of the requirements for the degree of MA in English. Department of English University of Rajshahi, Rajshahi, Bangladesh.

[16] Ransom, G.A. (1978). Preparing to Teach Reading. Boston: Little, Brown and Company.

[17] Rauch, S. J. \& Weinstein, A. B. (1968). Mastering Reading Skills. New York: D. Van Nostrand Company.

[18] Rayner, K. \& Pollatsek, A. (1989). The Psychology of Reading. New Jersey: Prentice-Hall.

[19] Rice, M. (2009). Research-Based Reading Instruction: Reading Comprehension Skills and Strategies--- Florida Center for Reading Research: Making Connections. Educators Publishing Service. Retrieved from http://www.fcrr.org/FCRRREPORTS on June, 24, 2012.

[20] Song, M. (1998). Teaching Reading Strategies in an Ongoing EFL University Reading Classroom. Seoul National University . Asian Journal of English Language Teaching Vol. 8, 1998, pp. 41-54.

[21] Urquhart, S. \& Weir, C. (1998). Reading in a Second Language: Process, Product and Practice. London: Longman.

[22] Vacca, R.T. (2002). Making a Difference in Adolescents' School Lives: Visible and Invisible Aspects of Content Area Reading. In A.E. Farstrup \& S.J. Samuels (Eds.). What Research Has To Say About Reading Instruction (3rd ed., pp. 184-204). Newark, DE: International Reading Association.

[23] Williams, E. (1996). Reading in the Language Classroom. Malaysia: Modern English Publications.

[24] Zhang, Z. (1992). English Reading Strategies. Bijing: Transportation Press.

[25] Zhang, Z. (1993). Literature Review on Reading Strategy Research. A Paper presented at the Annual Meeting of the Mid-South Educational Research Association. New Orleans, LA, November, 10-12.

Sumaira Qanwal is a Lecturer in English in COMSATS Institute of Information Technology, Pakistan. She has obtained the degrees of, 'Master of Philosophy in Linguistics' (2012) and 'Master in English Language and Literature' (2008) from The Islamia University of Bahawalpur, Pakistan.

Shahzad Karim is a professional language teacher. Currently, he is working as an English Language Instructor in King Abdul Aziz University Jeddah, Saudi Arabia. He is also working as an Assistant Professor in the Department of English, The Islamia 
University of Bahawalpur Pakistan. He has got the degrees of 'Master of Professional Studies - Language Teaching' from The University of Auckland New Zealand (2009), 'Master of Philosophy in Linguistics' (2008) and 'Master in English Language and Literature' (2003) from Pakistan. He has got his research papers published in national and international research journals. He has also authored a book titled 'Implicit and Explicit knowledge and medium of instruction in Pakistan' published by Lambert Academic Publishing (LAP) Germany (2011). 